\title{
Chemical composition, toxicity and larvicidal and antifungal activities of Persea americana (avocado) seed extracts
}

\section{Composição química, toxicidade, atividade larvicida e antifúngica de extratos de semente de Persea americana (abacate)}

\author{
João Jaime Giffoni Leite ${ }^{1,2}$, Érika Helena Salles Brito ${ }^{1,4}$, Rossana Aguiar Cordeiro ${ }^{1,4}$, \\ Raimunda Sâmia Nogueira Brilhante ${ }^{1,3}$, José Júlio Costa Sidrim ${ }^{1,2}$, Luciana Medeiros Bertini ${ }^{5}$, \\ Selene Maia de Morais ${ }^{4}$ and Marcos Fábio Gadelha Rocha ${ }^{1,4}$
}

\begin{abstract}
The present study had the aim of testing the hexane and methanol extracts of avocado seeds, in order to determine their toxicity towards Artemia salina, evaluate their larvicidal activity towards Aedes aegypti and investigate their in vitro antifungal potential against strains of Candida spp, Cryptococcus neoformans and Malassezia pachydermatis through the microdilution technique. In toxicity tests on Artemia salina, the hexane and methanol extracts from avocado seeds showed $\mathrm{LC}_{50}$ values of 2.37 and $24.13 \mathrm{mg} \mathrm{mL}^{-1}$ respectively. Against Aedes aegypti larvae, the $\mathrm{LC}_{50}$ results obtained were $16.7 \mathrm{mg} \mathrm{mL}^{-1}$ for hexane extract and $8.87 \mathrm{mg} \mathrm{mL}^{-1}$ for methanol extract from avocado seeds. The extracts tested were also active against all the yeast strains tested in vitro, with differing results such that the minimum inhibitory concentration of the hexane extract ranged from 0.625 to $1.25 \mathrm{mg} \mathrm{L}^{-1}$, from 0.312 to $0.625 \mathrm{mg} \mathrm{mL}^{-1}$ and from 0.031 to $0.625 \mathrm{mg} \mathrm{mL}^{-1}$, for the strains of Candida spp, Cryptococcus neoformans and Malassezia pachydermatis, respectively. The minimal inhibitory concentration for the methanol extract ranged from 0.125 to $0.625 \mathrm{mg} \mathrm{mL}^{-1}$, from 0.08 to $0.156 \mathrm{mg} \mathrm{mL}^{-1}$ and from 0.312 to $0.625 \mathrm{mg} \mathrm{mL}^{-1}$, for the strains of Candida spp., Cryptococcus neoformans and Malassezia pachydermatis, respectively.
\end{abstract}

Key-words: Avocado seeds. Artemia salina. Aedes aegypti. Yeasts.

\section{RESUMO}

0 presente estudo teve como objetivo testar os extratos hexânico e metanólico das sementes do abacate, a fim de determinar sua toxicidade em Artemia salina, avaliar a atividade larvicida frente ao Aedes aegypti, bem como verificar o potencial antifúngico in vitro contra cepas de Candida spp, Cryptococcus neoformans e Malassezia pachydermatis, através da técnica de microdiluição. Os extratos hexânico e metanólico das sementes de abacate apresentaram no teste de toxicidade frente à Artemia salina, valores de $\mathrm{LC}_{50} 2,37$ e 24,13mg L ${ }^{-1}$, respectivamente; contra as larvas do Aedes aegypti os resultados obtidos foram $\mathrm{LC}_{50} 16,7 \mathrm{mg} \mathrm{L}^{-1}$ para o extrato hexânico e $8,87 \mathrm{mg} \mathrm{L}^{-1}$ para o extrato metanólico das sementes do abacate. 0 s extratos testados também foram ativos contra todas as cepas de leveduras, testadas in vitro, apresentando diferentes resultados, onde o MIC do extrato hexânico variou de 0,625 a 1,25 $\mathrm{mg} \mathrm{mL}^{-1}$, de 0,312 a $0,625 \mathrm{mg} \mathrm{mL}^{-1}$ e de 0,031 a $0,625 \mathrm{mg} \mathrm{mL}^{-1}$ para as cepas de Candida spp., Cryptococcus

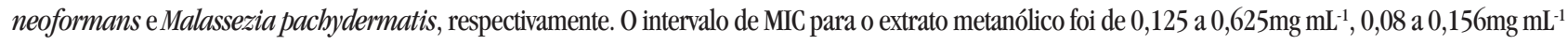
e de 0,312 a 0,625 $\mathrm{mg} \mathrm{mL}^{-1}$, para as exemplares de Candida spp., Cryptococcus neoformans e Malassezia pachydermatis, respectivamente.

Palavras-chaves: Sementes do abacate. Artemia salina. Aedes aegypti. Leveduras.

Persea americana Mill. (Lauraceae) is a plant from Central America (Mexico, Guatemala, Antilles), but it has shown easy adaptation to other tropical regions. Its fruits are commonly known as avocados and have an olive-green peel and thick pale yellow pulp that is rich in vegetable oils and appreciated for its sensory attributes. There is a global tendency towards fruit processing and, following such industrial processes, byproducts

1. Centro Especializado em Micologia Médica, Universidade Federal do Ceará, Fortaleza, CE. 2. Programa de Pós-Graduação em Microbiologia Médica, Universidade Federal do Ceará, Fortaleza, CE. 3. Departamento de Ciências Biológicas, Universidade Estadual do Ceará, Fortaleza, CE. 4. Programa de Pós-Graduação em Ciências Veterinárias, Universidade Estadual do Ceará, Fortaleza, CE. 5. Programa de Pós-Graduação em Química, Universidade Federal do Ceará, Fortaleza, CE.

Address to: MSc. João Jaime G. Leite. R. Aracati 149, Benfica, 60020-240 Fortaleza, CE. Tel: 5585 3252-2958

e-mail:jjgiffoni@yahoo.com.br

Recebido para publicação em 15/10/2008

Aceito em 11/01/2009 like avocado seeds are normally discarded. However, these byproducts from industrialization can cause ecological problems like increased numbers of insects and rodents. In addition, there are economic losses due to the high cost of transporting these byproducts to disposal areas ${ }^{6}$. Thus, studies to investigate the benefits of these byproducts as sources of food supplements or medicinal products are needed ${ }^{21}$.

From the perspective of the use of avocado seeds as sources of phytotherapeutic agents, they have traditionally been used to treat mycoses and parasitic infections. Furthermore, avocado seed preparations are known to have local anesthetic effects that decrease muscle pain ${ }^{21}$.

Previous phytochemical studies on avocado seeds have identified various classes of natural products such as phytosterols, triterpenes, fatty acids, furanoic acids, flavonol dimers, proanthocyanidins and abscisic acid. Some of them are related to antifungal activity ${ }^{1}$ and larvicidal effect ${ }^{15}$. 
In the present study, the methanol and hexane extracts of avocado seeds were tested with regard to their toxicity, using the microcrustaceus Artemia salina and third-stage Aedes aegypti larvae. In addition, their antifungal potential using the microdilution method was evaluated against Candida spp, Cryptococcus neoformans and Malassezia pachydermatis.

\section{MATERIAL AND METHODS}

Botanical material. The seeds used in this study were obtained from a food industry located in Fortaleza, Ceará, Brazil, during August and September 2005. The cultivars were located in the State of Ceará, and especially within the metropolitan region of Fortaleza.

Sample preparation. The seeds had previously been separated from the pulp, dried in an oven at $50^{\circ} \mathrm{C}$ and ground into powder in a laboratory mill, and were kept wrapped in filter paper cartridges. The extracts were obtained by heat extraction using the reflux method (Soxhlet), using hexane and methanol separately as solvents for six hours. They were named hexane extract of avocado seeds (HEAS) and methanol extract of avocado seeds (MEAS), respectively. The extracts were concentrated in a rotary evaporator, under reduced pressure $\left(60 \mathrm{rpm}\right.$ at $\left.80^{\circ} \mathrm{C}\right)$.

Toxicity tests using Artemia salina. These assays were developed as described by Krishnaraju et $\mathrm{a}^{10}$, with modifications. Thus, 50mg of hexane and methanol extracts from avocado seeds were weighed and dissolved in 500 $\mu$ of dimethyl sulfoxide (DMSO). Seawater was added up to a final volume of $50 \mathrm{~mL}$. Different concentrations were obtained through dilutions, thus resulting in final concentrations of $1,10,100$ and $1,000 \mathrm{mg} \mathrm{mL}^{-1}$. The assays were performed in triplicate, and a control assay was performed using only DMSO and seawater. Artemia salina larvae were added and, after $24 \mathrm{~h}$ of contact, the survivors were counted and the mean lethal concentration $\left(\mathrm{LC}_{50}\right)$ was determined.

Larvicidal activity against Aedes aegypti. To detect larvicidal activity, third-stage Aedes aegypti larvae were used. Different masses of extract were dissolved in 300 $\mu \mathrm{l}$ of DMSO, and $19.7 \mathrm{~mL}$ of water were added to obtain solutions, thus resulting in concentrations of 500, 250, 100 and $50 \mathrm{mg} \mathrm{mL}^{-1}$. These were tested against 50 Aedes aegypti larvae. This assay was performed in triplicate at $28 \pm 1^{\circ} \mathrm{C}$ with relative air humidity of $80 \pm 5 \%$ and light/dark cycling every $12 \mathrm{~h}$. All the experiments were followed by performing a control series with the same number of larvae in DMSO and water. Mortality was observed $24 \mathrm{~h}$ after exposure. In accordance with the mortality found from the initial concentrations, intermediate concentrations were tested in order to determine the $\mathrm{LC}_{50}$ of the samples ${ }^{3}$.

Fungal strains. The fungal strains were obtained from the Specialized Medical Mycology Center, Federal University of Ceará, Brazil. Candida spp and Malassezia pachydermatis strains were isolated from healthy dogs and Cryptococcus neoformans from pigeon feces.

Antifungal activity. The sensitivity of antifungal agents was evaluated using microdilution in Roswell Park Memorial Institute
(RPMI) 1640 broth, in accordance with the methodology suggested by CLSI (Clinical Laboratory Standard Institute) for Candida spp and Cryptococcus neoformans strains. The inoculum of the yeast was adjusted to obtain 2.5 to $5 \times 10^{3}$ cells/mL. Negative and positive controls were added to each 96-well plate, and each yeast was also tested with DMSO and its dilutions. The microplates were incubated at $32^{\circ} \mathrm{C}$ for $48 \mathrm{~h}$. The test readings were done by visual comparison. For Malassezia pachydermatis yeast, the method of microdilution in RPMI 1640 was used, supplemented with (per liter): $20 \mathrm{~g}$ of glucose, $4 \mathrm{~g}$ of ox bile, $1 \mathrm{~mL}$ of glycerol, $0.5 \mathrm{~g}$ of glycerol monostearate and $0.4 \mathrm{~mL}$ of Tween $20^{22}$. The inoculum of the yeast was adjusted to obtain a 2.5 to $5 \times 10^{3}$ cells $/ \mathrm{mL}$. Negative and positive controls were added to each 96-well plate, and each yeast was also tested with DMSO and its dilutions. The microplates were incubated at $32^{\circ} \mathrm{C}$ for $48 \mathrm{~h}$. According to Prado et $\mathrm{al}^{18}$, for minimum inhibitory concentration (MIC) determination of Malassezia pachydermatis, $1 \mu \mathrm{l}$ from each well needs to be transferred to and distributed on Petri dishes with potato-dextrose agar, after this period. These dishes were incubated at $32^{\circ} \mathrm{C}$ and, after $96 \mathrm{~h}$, the fungal colonies were counted. The MIC was taken to be the lowest concentration capable of inhibiting $100 \%$ of the growth of each yeast, with its respective positive control as the reference ${ }^{12}$.

Phytochemical screening and isolation of compounds. The phytochemical screening was developed using the methodology described by Matos ${ }^{14}$, to determine the presence of flavonoids, anthocyanins, saponins, tannins, sterols, triterpenoids, fixed acids and alkaloids. The methyl esters were analyzed using the transmethylation technique followed by gas chromatography/mass spectrometry (GC/MS). The hexane extract was analyzed in a silica gel chromatographic column, using hexane, chloroform, ethyl acetate and methanol as eluents, in mixtures of increasing polarity. The ethyl acetate fraction was subjected to subsequent silica gel column chromatography following the same procedure as above. The fractions obtained were monitored chemically using thin layer chromatography (TLC), to achieve isolation of two compounds. The chemical structures of the compounds were determined by spectroscopic methods $\left({ }^{1} \mathrm{H}\right.$ and $\left.{ }^{13} \mathrm{C} \mathrm{NMR}\right)$ and comparison with authentic samples.

\section{RESULTS}

The HEAS and MEAS showed $\mathrm{LC}_{50}$ values of 2.37 and $24.13 \mathrm{mg} \mathrm{mL}^{-1}$ respectively, in the toxicity assays using Artemia salina. In the larvicidal assays, the extracts showed activity against Aedes aegypti, with $\mathrm{LC}_{50}$ of $8.87 \mathrm{mg} \mathrm{mL}^{-1}$ for HEAS and $16.7 \mathrm{mg} \mathrm{mL}^{-1}$ for MEAS (Table 1). The hexane and methanol extracts were active against all the yeasts tested by the microdilution method, and these results are reported in Table 2.

The preliminary phytochemical analyses revealed the presence of flavonoids, anthocyanins, condensed tannins, alkaloids and triterpenes in methanol extracts. Sterols and triterpenes were detected in the hexane extract. The HEAS lipid analysis showed the presence of palmitic acid (21.3\%), palmitoleic acid (1.6\%), stearic acid $(2.2 \%)$, oleic acid $(24.1 \%)$ and linoleic acid (27.6\%). The compounds isolated from HEAS were identified by ${ }^{1} \mathrm{H}$ and ${ }^{13} \mathrm{C}$ NMR data as 1,2,4-trihydroxy-nonadecane and $\beta$-sitosterol (Figure 1). 


\section{TABLE 1}

Lethal concentration $\left(\mathrm{LC}_{\mathrm{sp}}\right)$ of avocado seed extracts against Artemia salina and Aedes aegypti larvae.

\begin{tabular}{lcc}
\hline & \multicolumn{2}{c}{$\mathrm{LC}_{50}\left(\mathrm{mg} \mathrm{L}^{-1}\right)$} \\
\cline { 2 - 3 } Extracts & Artemia salina & Aedes aegypti \\
\hline HEAS & 2.37 & 8.87 \\
MEAS & 24.13 & 16.7 \\
\hline
\end{tabular}

HEAS: hexane extract of avocado seeds, MEAS: methanol extract of avocado seeds.

TABLE 2

Minimum inhibitory concentration (MIC) of avocado (Persea americana) seed extracts against Candida spp, Cryptococcus neoformans and Malassezia pachydermatis

\begin{tabular}{lccr}
\hline Fungi & & MIC (mg L & \\
& Number & HEAS & MEAS \\
\hline Candida parapsilosis & 4 & $1.25(2)^{*}$ & $0.625(4)$ \\
& & $0.625(2)$ & \\
\hline Candida tropicalis & 4 & $0.625(3)$ & $0.625(3)$ \\
& & $0.312(1)$ & $0.312(1)$ \\
\hline Candida albicans & 2 & $0.625(2)$ & $0.625(1)$ \\
& & & $0.125(1)$ \\
\hline Candida krusei ATCC 6528 & 1 & $0.625(1)$ & $0.625(1)$ \\
\hline Cryptococcus neoformans & 1 & $0.625(1)$ & $0.625(1)$ \\
\hline Malassezia pachydermatis & 6 & $0.625(1)$ & $0.156(1)$ \\
& & $0.312(5)$ & $0.08(5)$ \\
\hline
\end{tabular}

HEAS: hexane extract of avocado seeds, MEAS: methanol extract of avocado seeds, MIC: minimum inhibitory concentration, *represents the number of strains for the MIC indicated.

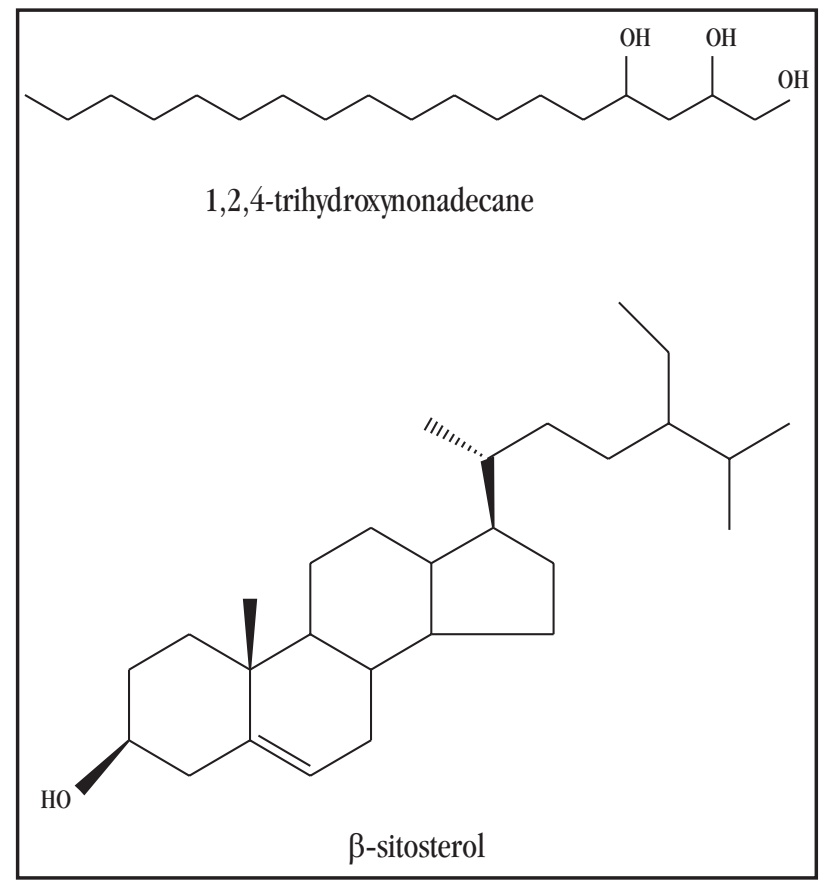

FIGURE 1

Molecular structure of the compounds identified from the hexane extract of avocado seeds.

\section{DISCUSSION}

In the present study, the various extracts were submitted to toxicity assays using Artemia salina. They were considered bioactive, since they showed an $\mathrm{LC}_{50}$ lower than $1,000 \mathrm{mg} \mathrm{mL}^{-115}$. The hexane extract from avocado seeds showed the highest toxicity to Artemia salina $\left(\mathrm{LC}_{50}\right.$ of $\left.2.37 \mathrm{mg} \mathrm{mL}^{-1}\right)$.

Determination of the toxicity to Artemia salina has been used efficiently to analyze the biological potential of plant extracts. Several natural products, especially substances with antifungal, antiviral, antibacterial and trypanosomicidal activity, have been tested through this assay, showing a significant relationship. Parra et al ${ }^{18}$ showed that it is a fast, simple, practical and low cost assay. Moreover, it avoids unnecessary use of animals in laboratories, because the $\mathrm{LC}_{50}$ and $\mathrm{LD}_{50}$ values show a good relationship between in vivo tests, with a rate of $r=0.85$. In addition, this method requires small quantities of the samples that can be tested on a large scale.

Both extracts showed larvicidal effects, but the highest larval mortality was found in the hexane extract of Persea americana. Rahuman et a ${ }^{20}$ demonstrated that the petroleum ether extract of Abutilon indicum showed high larvicidal activity against Aedes aegypti, Anopheles stephensi and Culex quinquefasciatus due to the presence of $\beta$-sitosterol in the extract composition. In a previous phytochemical study, Oberlies et $\mathrm{al}^{16}$ isolated the compounds: 1,2,4-trihydroxy-nonadecane, 1,2,4-trihydroxyheptadec-16-ene, and 1,2,4-trihydroxy-heptadec-16-yne from unripe avocado fruits, that showed the following values of toxicity $\left(\mathrm{LC}_{50}\right)$ of $2.8 ; 1.3$ and $6.4 \times 10^{-1} \mathrm{mg} \mathrm{mL}^{-1}$, respectively, using Artemia salina. Against Aedes aegypti larvae, the $\mathrm{LC}_{50}$ values were 1.8, 2.1 x $10^{-1}$ and $7.5 \times 10^{-2} \mathrm{mg} \mathrm{mL}^{-1}$, respectively. $\beta$-sitosterol and $1,2,4-$ trihydroxy-nonadecane were detected in the hexane extract from Persea americana seeds and may be responsible for its larvicidal activity.

This study also investigated the antifungal potential of avocado seed extracts against Candida spp, Cryptococcus neoformans and Malassezia pachydermatis. These yeasts are of great importance for human and veterinary medicine ${ }^{2}$. Candida species are one of the main agents responsible for fungal infections in hospitals. Recently, cases of antifungal resistance within this fungal group have been described. The avocado seed extracts induced inhibition of the growth of Candida species tested, producing MIC for HEAS ranging from 0.312 to $1.25 \mathrm{mg} \mathrm{mL}^{-1}$ and for MEAS from 0.125 to $0.625 \mathrm{mg} \mathrm{mL}^{-1}$. The HEAS MIC values ranged from 0.031 to $0.625 \mathrm{mg} \mathrm{mL}^{-1}$ and, for MEAS, from 0.321 to $0.625 \mathrm{mg} \mathrm{mL}^{-1}$ for Malassezia pachydermatis strains. Malassezia pachydermatis has high veterinary importance because of its intense pathological activity on carnivorous animals, but has also been related to fungemia cases among neonates ${ }^{4}$.

The extracts demonstrated lower concentration ranges against Cryptococcus neoformans strains, with values from $0.312 \mathrm{mg} \mathrm{mL}^{-1}$ $(\mathrm{n}=5)$ to $0.625 \mathrm{mg} \mathrm{mL}^{-1}(\mathrm{n}=1)$ for HEAS, and from $0.08 \mathrm{mg} \mathrm{mL}^{-1}(\mathrm{n}=6)$ to $0.156 \mathrm{mg} \mathrm{mL}^{-1}(\mathrm{n}=1)$ for MEAS. Cryptococcus neoformans is a yeast of essentially opportunist action that is responsible for cryptococcosis cases among HIV-positive patients ${ }^{13}$. The MIC values obtained against Cryptococcus neoformans strains were lower than the values against Candida spp and Malassezia pachydermatis strains. 
In addition to its anti-atherogenic and anticancer activity, $\beta$-sitosterol has been reported to have anti-inflammatory, antimicrobial, anti-bacterial and anti-fungal effects ${ }^{17}$. Lall et al ${ }^{11}$ isolated six compounds of Euclea natalensis and assayed them against Aspergillus flavus, Aspergillus niger and Cladosporium cladosporioides. $\beta$-sitosterol showed the best inhibitory activity against all the fungi tested except Aspergillus flavus. Some fatty acids also exhibit antimicrobial activity and this action is related to the presence and position of a double or triple bond, as well as the length of the fatty acid chain $\left(>\mathrm{C}_{14}\right)$. Optimal antimicrobial activity was found for fatty acids and their corresponding monoglycerides when the chain length was $\mathrm{C}_{12}{ }^{9}$. The methanol extracts showed the presence of phenol compounds such as flavonoids and anthocyanins, for which antimicrobial activity has been reported, and alkaloids with several actions such as antiviral, antimalarial and antiamoebic activity ${ }^{8}$.

In our previous studies on natural products against fungi ${ }^{7}$, MIC values $\leq 1.00 \mathrm{mg} \mathrm{mL}^{-1}$, as obtained in this study, represented important data in the search for phytotherapy drugs with antifungal potential. Furthermore, the extracts obtained from avocado seeds (Persea americana Mill.) and their constituents represent possible candidates for use as alternative dengue control agents, and also act as antifungal agents against pathogenic yeasts.

\section{REFERENCES}

1. Alcerito T, Barbo FE, Negri G, Santos DYAC, Meda CI, Young MCM, Chávez D, Blatt CTT. Foliar epicuticular wax of Arrabidaea brachypoda: flavonoids and antifungal activity. Biochemical Systematics and Ecollogy 30: 677-683, 2002.

2. Brito EHS, Fontenelle ROS, Brilhante RSN, Cordeiro RA, Soares Júnior FA, Monteiro AJ, Sidrim JJC, Rocha MFG. Phenotypic characterization and in vitro antifungal sensitivity of Candida spp and Malassezia pachydermatis strains from dogs. The Veterinary Journal 174: 147-153, 2007.

3. Céspedes CL, Salazar JR, Martinez M, Aranda E. Insect growth regulatory effects of some extracts and sterols from Myrtillocactus geometrizans (Cactaceae) against Spodoptera frugiperda and Tenebrio molitor. Phytochemistry 66: 2481, 2005.

4. Chryssantho UE, Broberge RU, Petrini B. Malassezia pachydermatis fungemia in a neonatal intensive care unit. Acta Paediatrica 90:323-327, 2001.

5. Citó AMGL, Souza AA, Lopes JAD, Chaves MH, Costa FB, Souza SAA, Amaral MPM. Resina de Protium heptaphyllum March (Burceraceae). Composição química do óleo essencial e avaliação citotóxica frente a Artemia salina Leach. Anais da Associação Brasileira de Química 52: 74-76, 2003.

6. Ferrari RA, Colussi F, Ayub RA. Caracterização de subprodutos da industrialização do maracujá- aproveitamento das sementes. Revista Brasileira de Fruticultura 26:101-102, 2004.

7. Fontenelle ROS, Morais SM, Brito EHS, Kerntopf MR, Brilhante RSN, Cordeiro RA, Tomé AR, Queiroz MR, Nascimento NRF, Sidrim JJC, Rocha MFG.
Chemical composition, toxicological aspects and antifungal activity of essential oil from Lippia sidoides Cham. Journal of Antimicrobial Chemotherapy 59: 934-940, 2007.

8. Henriques AT, Limberger RP, Keber VA, Moreno PRH. Alcalóides: generalidades e aspectos básicos. In: Simões CMO, Schenkel EP, Gosmann G, Mello JCP, Mentz LA, Petrovick PR (eds) Farmacognosia: da planta ao medicamento, $5^{\text {nd }}$ edition, UFSC, Florianópolis, p.765-793, 2004.

9. Kabara JJ, Vrable R, Lie Ken Jie MSF. Antimicrobial lipids: Natural and synthetic fatty acids and monoglycerides. Lipids 12: 753-759, 1977.

10. Krishnaraju AV, Rao TVN, Sundararaju D, Vanisree M, Tsay HS, Subbaraju GV. Biological screening of medicinal plants collected from eastern ghats of india using Artemia salina (Brine Shrimp Test). The International Journal of Applied Science, Engineering and Technology 4: 115-125, 2006.

11. Lall N, Weiganand O, Hussein AA, Meyer JJM. Antifungal activity of naphthoquinones and triterpenes isolated from theroot bark of Euclea natalensis. South African Journal of Botany 72:579-583, 2006

12. Longhini R, Raksa SM, Oliveira ACP, Svidzinski TIE, Franco SL. Obtenção de extratos de própolis sob diferentes condições e avaliação de sua atividade antifúngica. Revista Brasileira de Farmacognosia 17: 388-395, 2007.

13. Manfredi R, Calza L, Chiodo F. AIDS-associated Cryptococcus infection before and after the highly active antiretroviral therapy era: emerging management problems. International Journal of Antimicrobial Agents 22:449-452, 2003.

14. Matos FJA. Introdução a Fitoquímica Experimental, $2^{\text {nd }}$ edition, UFC, Fortaleza, Brasil, 2000.

15. Morais SM, Facundo VA, Bertini LM, Cavalcanti ESB, Anjos Júnior JF, Ferreira SA, Brito ES, Souza Neto MA. Chemical composition and larvicidal activity of essential oils from Piper species. Biochemical Systematics and Ecollogy 35: 670-675, 2007.

16. Oberlies NH, Rogers LL, Martin JM, McLaughlin JL. Cytotoxic and Insecticidal Constituents of the Unripe Fruit of Persea americana. Journal of Natural Products 61: 781-785, 1998 .

17. Ovesná Z, Vachálková A, Horváthová K. Taraxasterol and beta-sitosterol: New naturally compounds with chemoprotective/chemopreventive effects. Neoplasma 51:407-414, 2004.

18. Parra AL, Yhebra RS, Sardiñas IG, Buela LI. Comparative study of the assay of Artemia salina L. and the estimate of the medium lethal dose (LD50 value) in mice, to determine oral acute toxicity of plant extracts. Phytomedicine 8:395-400, 2001.

19. Prado MR, Brito ÉHS, Brilhante RSN, Cordeiro RA, Leite JJG, Sidrim JJC, Rocha MFG. Subculture on potato dextrose agar as a complement to the broth microdilution assay for Malassezia pachydermatis. Journal of Microbiological Methods 75: 341-343, 2008.

20. Rahuman AA, Gopalakrishnan G, Venkatesan P, Geetha K. Isolation and identification of mosquito larvicidal compound from Abutilon indicum (Linn) Sweet. Parasitology Research 102: 981-988, 2008.

21. Ramos MR, Jerz G, Villanueva S, Lopez-Dellamary F, Waibe R, Winterhalter P. Two glucosylated abscisic acid derivates from avocado seeds (Persea americana Mill. Lauraceae cv. Hass). Phytochemistry 65: 955-962, 2004.

22. Velegraki A, Alexopoulos EC, Kritikou S, Gaitanis G. Use of Fatty Acid RPMI 1640 Media for Testing Susceptibilities of Eight Malassezia Species to the New Triazole Posaconazole and to Six Established Antifungal Agents by a Modified NCCLS M27-A2 Microdilution Method and Etest. Journal of Clinical Microbiology 42:3589-3593, 2004. 